\title{
16. INTERSTITIAL WATER STUDIES, LEG 78A ${ }^{1}$
}

\author{
Joris M. Gieskes, Scripps Institution of Oceanography \\ Henry Elderfield, Department of Earth Sciences, University of Cambridge \\ James R. Lawrence, Lamont-Doherty Geological Observatory \\ and \\ Judy LaKind, Scripps Institution of Oceanography ${ }^{2}$
}

\begin{abstract}
Studies of interstitial water carried out during Deep Sea Drilling Project Leg 78A (Sites 541, 542, and 543) have revealed that alteration of volcanic material dispersed in the sediments is largely responsible for increased concentrations of dissolved calcium and decreased concentrations of dissolved magnesium and potassium. This conclusion is supported by studies of the ${ }^{87} \mathrm{Sr} /{ }^{86} \mathrm{Sr}$ ratio of dissolved strontium, as well as by studies of the oxygen isotopic composition of interstitial waters. At Site 543 a large part of the $\delta^{18} \mathrm{O}$ decrease in the interstitial waters must result from diffusive exchange with underlying basement rocks. Data from studies of interstitial water do not indicate upward advection of fluids at Sites 541 and 542.
\end{abstract}

\section{INTRODUCTION}

During Leg 78A holes were drilled at three sites with the aim of studying the geophysics of a seismically defined deformation front associated with the Lesser Antilles forearc (Fig. 1). At Sites 541 and 542 holes were drilled into the seaward edge of the Barbados Ridge complex, and at Site 543 holes were drilled into the adjacent Atlantic ocean crust. Penetration was not great at either Site 541 or Site 542 , because of the drill was unable to penetrate a major deformation zone at $431 \mathrm{~m}$ sub-bottom at Site 541 and because the pipe stuck at Site 542. Valuable information was gained, however, on the nature of tectonic processes associated with the subduction of the Atlantic Plate under the Barbados Ridge complex (Moore and Biju-Duval, this volume).

At all three sites, interstitial water samples were obtained throughout the drilled sections, and at Site 541 the in situ interstitial water sampler was successfully deployed three times. Here we wish to report both the shipboard geochemical data and the data obtained in our own laboratories.

\section{METHODS}

For major and minor chemical analyses, the methods described by Gieskes (1974), Gieskes and Lawrence (1976), and Gieskes and Johnson (1981) were employed. Shipboard analyses included $\mathrm{Ca}, \mathrm{Mg}, \mathrm{pH}$, alkalinity, chlorinity, and salinity. The data are presented in Table 1.

Chloride contents are generally within $1 \%$ of the bottom-water value $(\sim 19.3 \mathrm{~g} / \mathrm{kg}$ ), except for lower values in one in situ sample (P.W. 2) and in a few samples collected at greater depths $(541-43-5,135-150 \mathrm{~cm}$; $541-48-4,135-150 \mathrm{~cm} ; 543 \mathrm{~A}-7-2,0-10 \mathrm{~cm}$ ). These lower values could result from slight contamination with distilled water during the squeezing process. Yet in only one sample $(541-43-5,135-150 \mathrm{~cm})$ is the chlorinity too low by $\sim 4 \%$, compared to the bottom water value, and this is

\footnotetext{
${ }^{1}$ Biju-Duval, B., Moore, J. C., et al., Init. Repts. DSDP, Vol. 78A: Washington (U.S. Govt, Printing Office).

2 Addresses: (Gieskes and LaKind) Scripps Institution of Oceanography, La Jolla, CA 92093; (Elderfield) Department of Earth Sciences, University of Cambridge, Cambridge CB3 OEZ, England; (Lawrence) Lamont-Doherty Geological Observatory, Palisades, NY 10964.
}

also reflected in low salinity. Concentrations of dissolved ammonia are rather scattered, which may result in part from oxidation of $\mathrm{NH}_{4}^{+}$during storage.

The ${ }^{87} \mathrm{Sr} /{ }^{86} \mathrm{Sr}$ ratio of dissolved strontium was determined using the methodology described by Hawkesworth and Elderfield (1978). The ${ }^{18} \mathrm{O} /{ }^{16} \mathrm{O}$ composition of interstitial waters was determined using the $\mathrm{CO}_{2}$ equilibration technique of Epstein and Mayeda (1953).

The lithologies of the sites are presented in Figure 2, as well as in the Figures 3, 4, and 5, which contain the interstitial water data.

\section{RESULTS}

DSDP interstitial water studies have revealed, at sites away from areas of rapid sediment accumulation, a general correlation between observed increases in concentrations of dissolved calcium in the interstitial waters and decreases in the $\delta^{18} \mathrm{O}$ of these waters (Lawrence and Gieskes, 1981; Gieskes and Lawrence, 1981). At many sites linear correlations between increases in calcium content and decreases in magnesium content are observed. McDuff (1981) showed that generally in such cases the source of dissolved calcium and the sink for magnesium are located in the basalts of Layer 2, rather than in the sediments. When correlations between calcium and magnesium contents are non-linear, reactions in the sediment column must be responsible; these reactions will then usually superimpose signals in calcium contentbut particularly in magnesium content-on the signals generated in the underlying basement (Gieskes and Lawrence, 1981). Using analyses of both the ${ }^{18} \mathrm{O} /{ }^{16} \mathrm{O}$ composition of the interstitial waters and the ${ }^{87} \mathrm{Sr} /{ }^{86} \mathrm{Sr}$ ratio of dissolved strontium, it has been shown that a major contributor to reactions in the sediment column is the alteration of volcanic matter (Gieskes and Lawrence, 1981; Hawkesworth and Elderfield, 1978; Elderfield and Gieskes, 1982; Gieskes, 1983). Considerations of mass balance, based on oxygen isotopic compositions of the interstitial waters, indicate, however, that much of the signal in $\delta^{18} \mathrm{O}$ and presumably in dissolved-calcium content are associated with alteration reactions in Layer 2 of the 

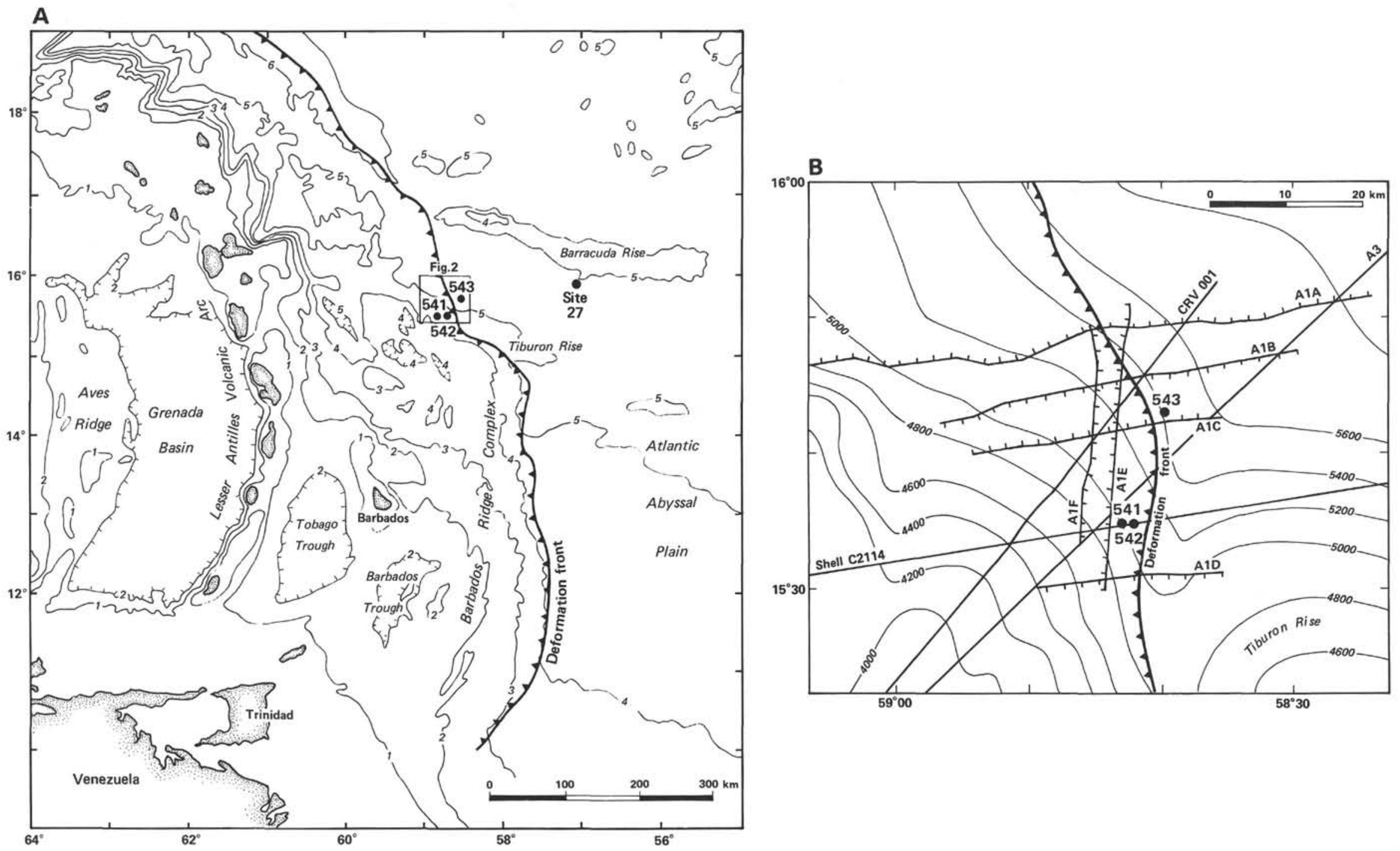

Figure 1. A. Regional location map. Note position of deformation front defining eastward boundary of Barbados Ridge complex and Tiburon Rise underthrusting deformation front near Sites 541 , 542 , and 543 (inset). Water depths in km. B. Detailed map (inset in Fig. 1A) showing positions of Leg 78A sites. Note position of deformation front and locations of seismic reflection lines used for site survey. Water depths in $\mathrm{m}$. 
Table 1. Analyses of interstitial water, Leg 78A.

\begin{tabular}{|c|c|c|c|c|c|c|c|c|c|c|c|c|c|c|c|c|}
\hline Hole & $\begin{array}{c}\text { Sample } \\
\text { (interval in } \mathrm{cm} \text { ) }\end{array}$ & $\begin{array}{l}\text { Sub-bottom } \\
\text { depth } \\
\text { (m) }\end{array}$ & $\mathrm{pH}$ & $\underset{(\mathrm{meq} / \mathrm{L})}{\mathrm{Alk}}$ & $\underset{(\mathrm{g} / \mathrm{kg})}{\mathrm{S}}$ & $\underset{(\mathrm{mM})}{\mathrm{Ca}}$ & $\begin{array}{c}\mathrm{Mg} \\
(\mathrm{mM})\end{array}$ & $\underset{(\mathrm{g} / \mathrm{kg})}{\mathrm{Cl}}$ & $\begin{array}{c}\mathrm{Sr} \\
(\mu \mathrm{M})\end{array}$ & ${ }^{87} \mathrm{Sr} /{ }^{86} \mathrm{Sr}$ & $\begin{array}{c}\mathrm{Li} \\
(\mu \mathrm{M})\end{array}$ & $\underset{(\mathrm{mM})}{\mathrm{K}}$ & $\begin{array}{c}\mathrm{SO}_{4} \\
(\mathrm{mM})\end{array}$ & $\begin{array}{l}\mathrm{NH}_{4} \\
(\mu \mathrm{M})\end{array}$ & $\begin{array}{c}\mathrm{Si} \\
(\mu \mathrm{M})\end{array}$ & $\delta^{18} \mathrm{O}_{\mathrm{S}_{0}}$ \\
\hline \multirow[t]{13}{*}{541} & $2-5,140-150$ & 8.5 & 7.40 & 2.91 & 36.6 & 18.5 & 40.2 & 19.29 & 132 & 0.70852 & 15.1 & 11.0 & 25.9 & 19 & 453 & - \\
\hline & $5-1,140-150$ & 31.0 & 7.49 & 1.57 & 36.0 & 24.1 & 36.3 & 19.73 & 207 & 0.70832 & 37.3 & 9.3 & - & 355 & 375 & -0.79 \\
\hline & P.W. $1^{\mathrm{a}}$ & 48.5 & 7.65 & 2.57 & 35.5 & 27.5 & 32.9 & 19.46 & - & - & - & - & - & - & - & -0.66 \\
\hline & $8-4,140-150$ & 64.0 & 7.03 & 1.60 & 36.6 & 25.0 & 31.2 & 19.66 & 249 & - & 22.5 & 8.4 & 25.7 & 199 & 247 & - \\
\hline & P.W. 2 & 95.0 & 8.94 & 1.70 & 33.8 & 24.7 & 34.6 & 17.97 & 220 & 0.70840 & 22.5 & 7.3 & 23.4 & 97 & 118 & -0.56 \\
\hline & $13-5,140-150$ & 113.0 & 7.44 & 0.73 & 35.8 & 26.8 & 29.1 & 19.53 & 279 & 0.70836 & 22.0 & 7.4 & - & 80 & 167 & -1.71 \\
\hline & P.W. 3 & 143.5 & 8.50 & 1.23 & 35.8 & 32.4 & 29.5 & 19.32 & 326 & 0.70834 & 37.5 & 4.5 & 24.8 & 191 & 153 & -1.08 \\
\hline & $18-4,140-150$ & 159.0 & 7.69 & 0.53 & 35.2 & 31.5 & 25.8 & 19.32 & 326 & 0.70824 & 22.0 & 6.5 & - & 301 & 147 & -1.34 \\
\hline & $23-3,140-150$ & 205.0 & 7.58 & 0.55 & 38.0 & 33.5 & 25.8 & 19.29 & 256 & 0.70841 & 22.0 & 5.3 & - & 27 & 164 & - \\
\hline & $33-4,138-150$ & 301.5 & 8.03 & 0.31 & 34.9 & 39.3 & 16.4 & 19.19 & 407 & 0.70824 & 51.4 & 5.0 & 25.2 & 231 & 149 & -1.31 \\
\hline & $38-5,135-150$ & 350.5 & 8.20 & 1.05 & 35.8 & 41.2 & 19.2 & 19.27 & 220 & 0.70746 & 37.5 & 4.4 & - & 246 & 119 & $(-1.13)$ \\
\hline & $43-5,135-150$ & 398.5 & 8.26 & 1.00 & 33.6 & 42.1 & 18.0 & 18.40 & 190 & - & 60.0 & 3.9 & - & 280 & 97 & -1.84 \\
\hline & $48-4,135-150$ & 450.0 & 7.00 & 1.55 & 35.2 & 42.9 & 20.9 & 18.94 & 166 & 0.70787 & 134.9 & 7.3 & 24.8 & 240 & 443 & - \\
\hline \multirow[t]{4}{*}{542} & H1-6, 0-07 & $0-88$ & 7.47 & 0.99 & 36.8 & 12.0 & 48.5 & 19.51 & 218 & 0.70844 & 22 & 8.7 & 25.4 & 135 & 184 & - \\
\hline & $\mathrm{H} 2-3,142-150$ & $88-154$ & 7.45 & 0.79 & 35.2 & 30.0 & 29.9 & 19.48 & 303 & 0.70836 & 37 & 7.0 & 25.7 & 308 & 169 & - \\
\hline & H3-2, 125-135 & $154-202$ & 7.90 & 0.38 & 36.3 & 37.0 & 25.2 & 19.51 & 355 & 0.70812 & 37 & 6.5 & - & 125 & 154 & - \\
\hline & $1-5,125-135$ & 209 & 7.72 & 0.50 & 35.8 & 35.7 & 28.1 & 19.51 & 333 & 0.70803 & 37 & 5.5 & - & 201 & 147 & -1.34 \\
\hline \multirow[t]{2}{*}{$542 \mathrm{~A}$} & $3-2,140-150$ & 252 & 7.78 & 0.91 & 35.2 & 41.6 & 27.3 & 18.97 & 196 & 0.70746 & 53 & 4.1 & - & 21 & 147 & $(-3.59)$ \\
\hline & $8-4,135-150$ & 312 & 7.82 & 0.49 & 34.9 & 42.9 & 27.3 & 19.10 & 204 & 0.70750 & 74 & 4.6 & 25.4 & 227 & 117 & -2.31 \\
\hline \multirow[t]{6}{*}{543} & $2-4,140-150$ & 16 & 7.37 & 2.69 & 36.3 & 13.9 & 46.1 & 19.48 & 114 & 0.70881 & 15 & 10.6 & 29.2 & 38 & 315 & 0.00 \\
\hline & $5-3,140-150$ & 43 & 7.60 & 1.94 & 36.0 & 17.4 & 44.3 & 19.38 & 113 & 0.70835 & 15 & 9.4 & 31.4 & 129 & 182 & -0.09 \\
\hline & $9-5,140-150$ & 84 & 7.44 & 1.79 & 36.0 & 24.2 & 38.4 & 19.34 & 113 & 0.70812 & 15 & 7.6 & - & 97 & 172 & -0.062 \\
\hline & $19-4,140-150$ & 178 & 6.55 & 1.34 & 35.8 & 28.7 & 36.0 & 19.31 & 112 & 0.70801 & 82 & 7.5 & - & 149 & 927 & -1.09 \\
\hline & $26-4,140-150$ & 244 & 6.45 & 1.21 & 35.8 & 30.8 & 40.3 & 19.27 & 125 & 0.70877 & 120 & 7.0 & 28.9 & 113 & 1045 & -1.52 \\
\hline & $29-4,140-150$ & 273 & 6.13 & 0.85 & 36.0 & 32.6 & 39.1 & 19.27 & 112 & 0.70820 & 134 & 7.2 & - & 61 & 1000 & -1.97 \\
\hline \multirow[t]{3}{*}{$543 \mathrm{~A}$} & $2-1,140-150$ & 333 & 6.86 & 1.46 & 36.6 & 32.7 & 41.9 & 19.39 & 131 & 0.70821 & 105 & 6.9 & - & 198 & 619 & -1.63 \\
\hline & $7-2,0-10$ & 381 & 7.05 & 1.49 & 36.0 & 41.0 & 39.2 & 18.90 & 125 & - & 105 & 4.4 & 25.7 & 22 & 257 & -3.01 \\
\hline & $10-1,37-47$ & 408 & 7.14 & 1.07 & 36.3 & 39.2 & 39.4 & 19.34 & 130 & 0.70795 & 97 & 5.5 & 27.8 & 91 & 368 & -2.41 \\
\hline
\end{tabular}

Note: - indicates no data; $\mathrm{H}$ indicates wash core; data in brackets are of uncertain quality.

a P.W. = in situ

541

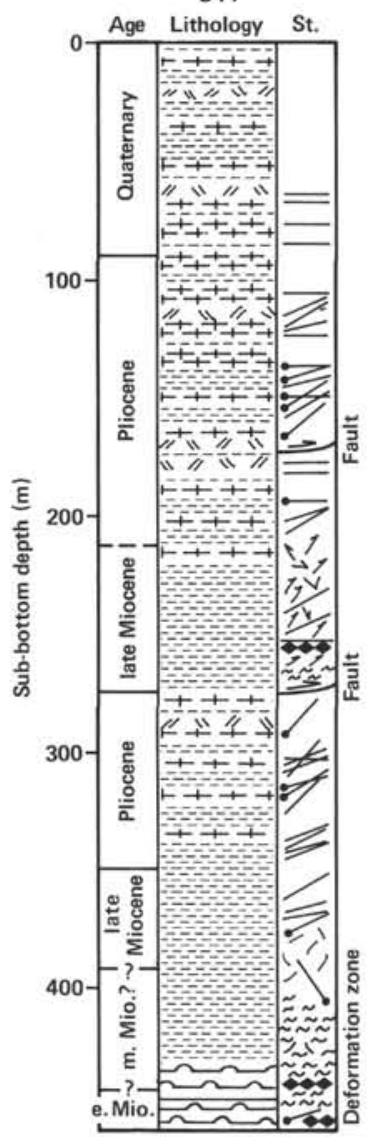

542

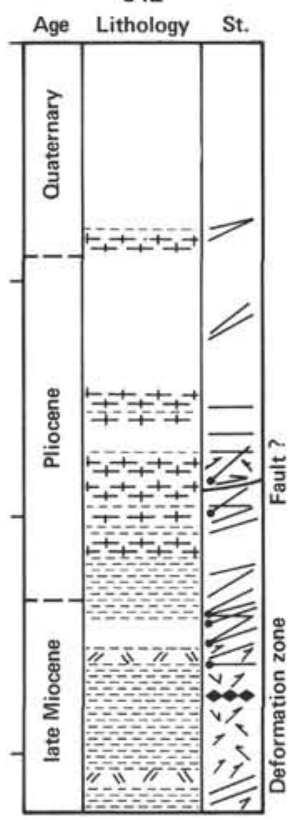

543

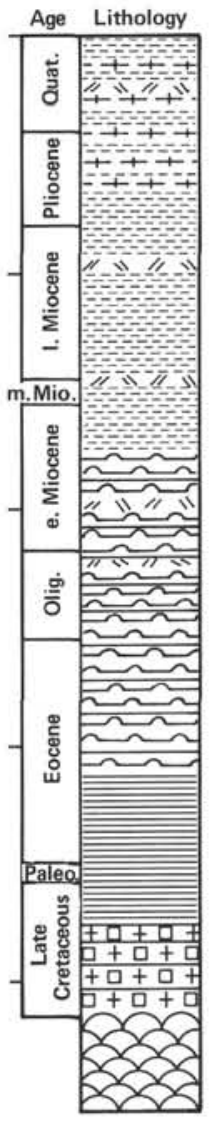

Parly nannofossil oo foraminifer ooze

+ \pm Nannofossil mud-mudstone Mud-mudstone Radiolarian clay-claystone Pelagic clay

$+0+0 \rightarrow$ Calcareous ferrugenous

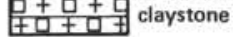

II 11 "I Pillow basalt

\section{$\longrightarrow$ Bedding \\ $\square$ Bedding, facing upright $\square$ Bedding, overturned ¿こ Discrete fractures common} $\mathrm{Z}^{\mathrm{t}}$ Slickensided surfaces common ( $\sim$ Scaly foliation Stratal disruption $\geqslant$ Thrust or reverse fault

Figure 2. Lithostratigraphy and structural geology at Sites 541, 542, and 543. 
ocean crust, and that the overprint resulting from alteration of volcanic matter in the sediments is relatively small (Lawrence et al., 1979; Lawrence and Gieskes, 1981).

The sediments cored during Leg 78A contain fairly large amounts of volcanic material. Shipboard interstitial water data on concentrations of dissolved calcium and magnesium indicate a nonlinear correlation between these elements at all three sites drilled (Fig. 6). This led us to decide on a concentrated program of study, not only of the major constituents of the interstitial waters, but also of the oxygen isotopic composition of the interstitial waters and the isotopic composition of dissolved strontium $\left({ }^{87} \mathrm{Sr} /{ }^{86} \mathrm{Sr}\right)$. This study constitutes the first intensive effort using this combined approach. In the following sections we discuss our observations at each site, and then conclude with more general discussions of the implications of the data.

\section{Site 541}

Notwithstanding fairly high recent rates of sediment accumulation, little sulfate reduction has occurred in the sediments at this site; this is also attested by the relatively small increases with depth in the concentration of dissolved ammonia. Alkalinity values show decreases with depth (Fig. 3), suggesting removal of bicarbonate from the interstitial waters, presumably as calcium carbonate. The relatively small decrease in alkalinity, however, would not noticeably affect trends in dissolved-calcium content. Of some interest is the consistent difference between in situ alkalinities and the alkalinity data from shipboard squeeze tests, the latter of which show lower values. This difference may result in part from calcium carbonate equilibria, as was shown for surface sediments by Emerson et al. (1982) and Jahnke et al. (1982). For the other components $\left(\mathrm{Ca}, \mathrm{Mg}, \mathrm{Sr},{ }^{87} \mathrm{Sr} /{ }^{86} \mathrm{Sr}, \mathrm{Si}, \mathrm{Li}\right.$, and $\mathrm{K}$ ), the agreement between in situ values and shipboard data is generally very good; the data on $\delta^{18} \mathrm{O}$ (cf. correlation of $\mathrm{Ca}$ and $\delta^{18} \mathrm{O}$, Fig. 6) may perhaps be slightly displaced.

The most important feature of Hole 541 is the rapid increase in dissolved-calcium content with depth in the upper $50 \mathrm{~m}$ (Fig. 3). With this are associated rapid decreases in dissolved-magnesium content and in the ${ }^{87} \mathrm{Sr} /$ ${ }^{86} \mathrm{Sr}$ ratio, as well as in the $\delta^{18} \mathrm{O}$ of the interstitial waters. The correlation between changes in concentrations of dissolved calcium and magnesium (Fig. 6) is almost lin-
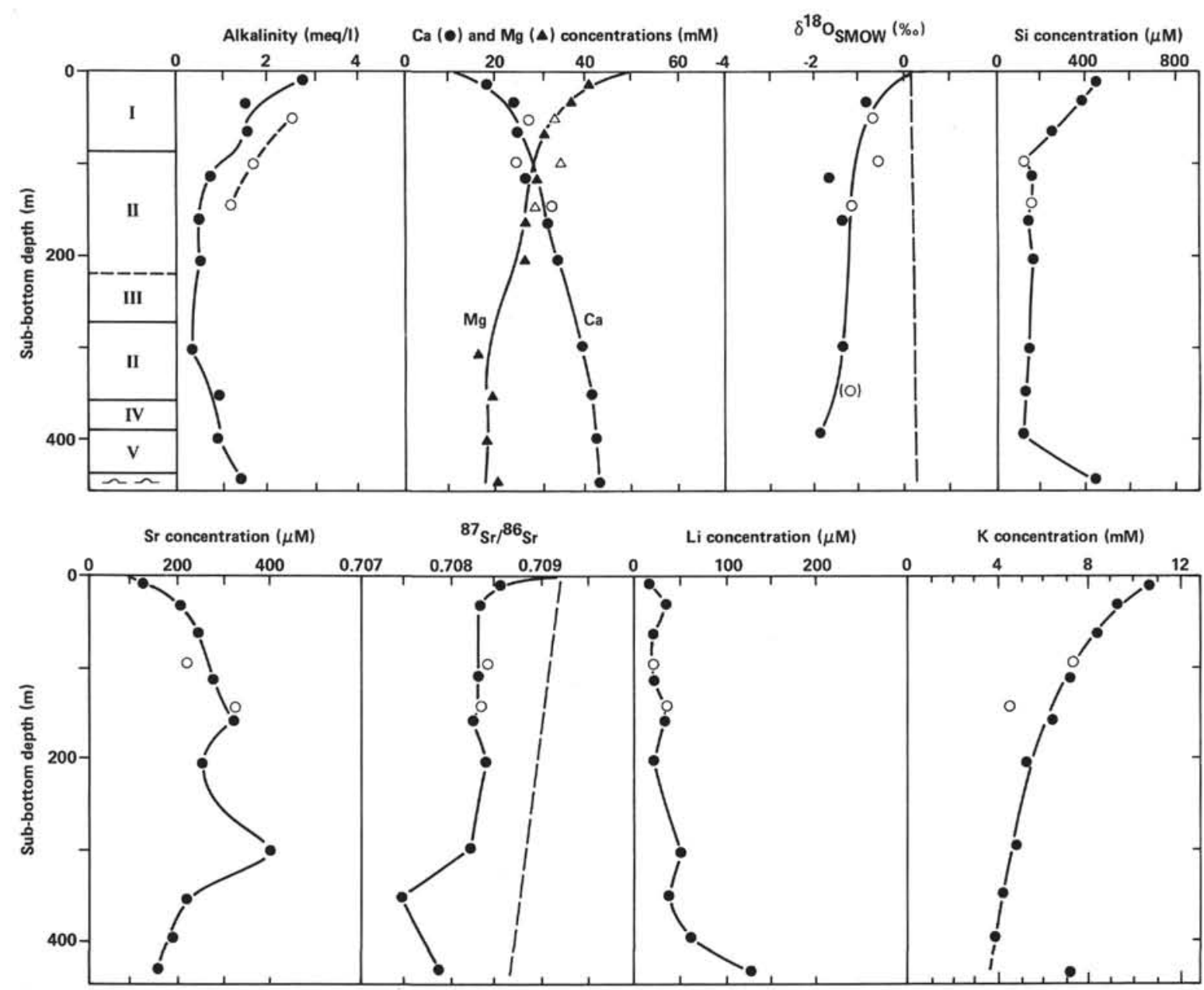

Figure 3. Interstitial water profiles, Site 541. Age units: I $=$ Quaternary, II $=$ Pliocene, III = lower Miocene, IV = middle Miocene, $\mathrm{V}=$ lower Miocene; see Figure 2. Dashed line $=$ contemporaneous seawater. Open symbols $=$ in situ data. 
ear (note that sampling artifacts do not necessarily imply an exact seawater end-member). The correlation between changes in dissolved-calcium content and $\delta^{18} \mathrm{O}$ is linear, within the accuracy of the data. There are two mechanisms by which these data can be explained: (1) the pore-water profiles are dominated by reactions involving alteration of volcanic matter, which is an important component in the upper sediment section; or (2) the curvature in the various concentration-vs.-depth profiles results from upward advection of interstitial waters from lower horizons. In a subsequent section we will argue against the second interpretation.

Evidence that alteration of volcanic matter contributes to the observed increases in dissolved-calcium content and decreases in magnesium and potassium contents comes from the sharp decrease in the isotope ratio of dissolved strontium. This rapidly decreases to a value of $\sim 0.7083$, well below the contemporaneous seawater value. The low ratio implies exchange with volcanic matter (Hawkesworth and Elderfield, 1978, Elderfield and Gieskes, 1982). In a subsequent section we shall return to this subject.

\section{Site 542}

Hole 542 was "washed" to $\sim 200 \mathrm{~m}$ sub-bottom, so that sediments retrieved from the core barrel could have come from anywhere in the washed interval (indicated by bars in Fig. 4). The concentration-vs.-depth profiles, therefore, are tentative and drawn by analogy with those for Hole 541.

Again, relatively large overall decreases in ${ }^{87} \mathrm{Sr} /{ }^{86} \mathrm{Sr}$ with depth indicate that substantial exchange with volcanic material must have occurred. Of some interest are the lower ${ }^{87} \mathrm{Sr} /{ }^{86} \mathrm{Sr}$ values in the lower Miocene section of Hole 542A (cf. the low value for Hole 541 in sediment of the same age). Perhaps more active exchange occurs in these sediments, or perhaps carbonate contributions are smaller-this problem will be addressed in a subsequent section.

The major-constituent profiles are very similar to those for Hole 541.

\section{Site 543}

Site 543 is the so-called Oceanic Reference Site, and was drilled to basaltic basement.

Throughout the Site 543 , alkalinity decreases with depth, and the profiles of calcium and magnesium concentrations (Fig. 5), which are nonlinearly correlated, clearly indicate that, especially for magnesium (minimum at $\sim 100 \mathrm{~m}$ sub-bottom), but also for calcium, reactions involving volcanic material must occur in the sediments. This again is indicated by the low ${ }^{87} \mathrm{Sr} /{ }^{86} \mathrm{Sr}$ values for the upper sediment column. The correlation between calcium and magnesium contents is nonlinear, and is quite different from those for Sites 541 and 542 . If relatively less removal of magnesium occurs in the up-
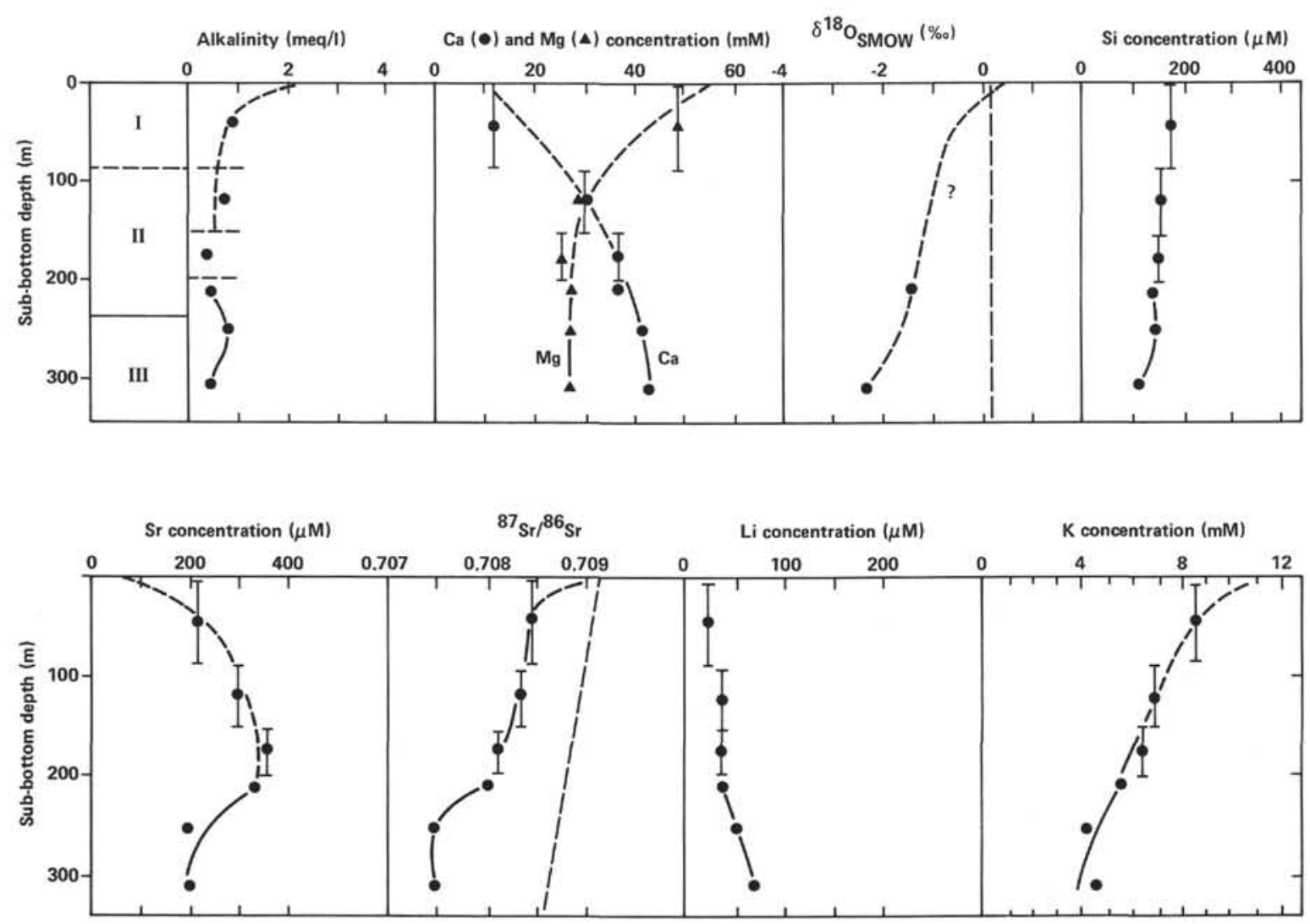

Figure 4. Interstitial water profiles, Site 542 (combining data from Table 1 for Holes 542 and 542A). Age units: $\mathrm{I}=$ Quaternary, II = Pliocene, III = lower Miocene; see Figure 2. Dashed line = contemporaneous seawater. 

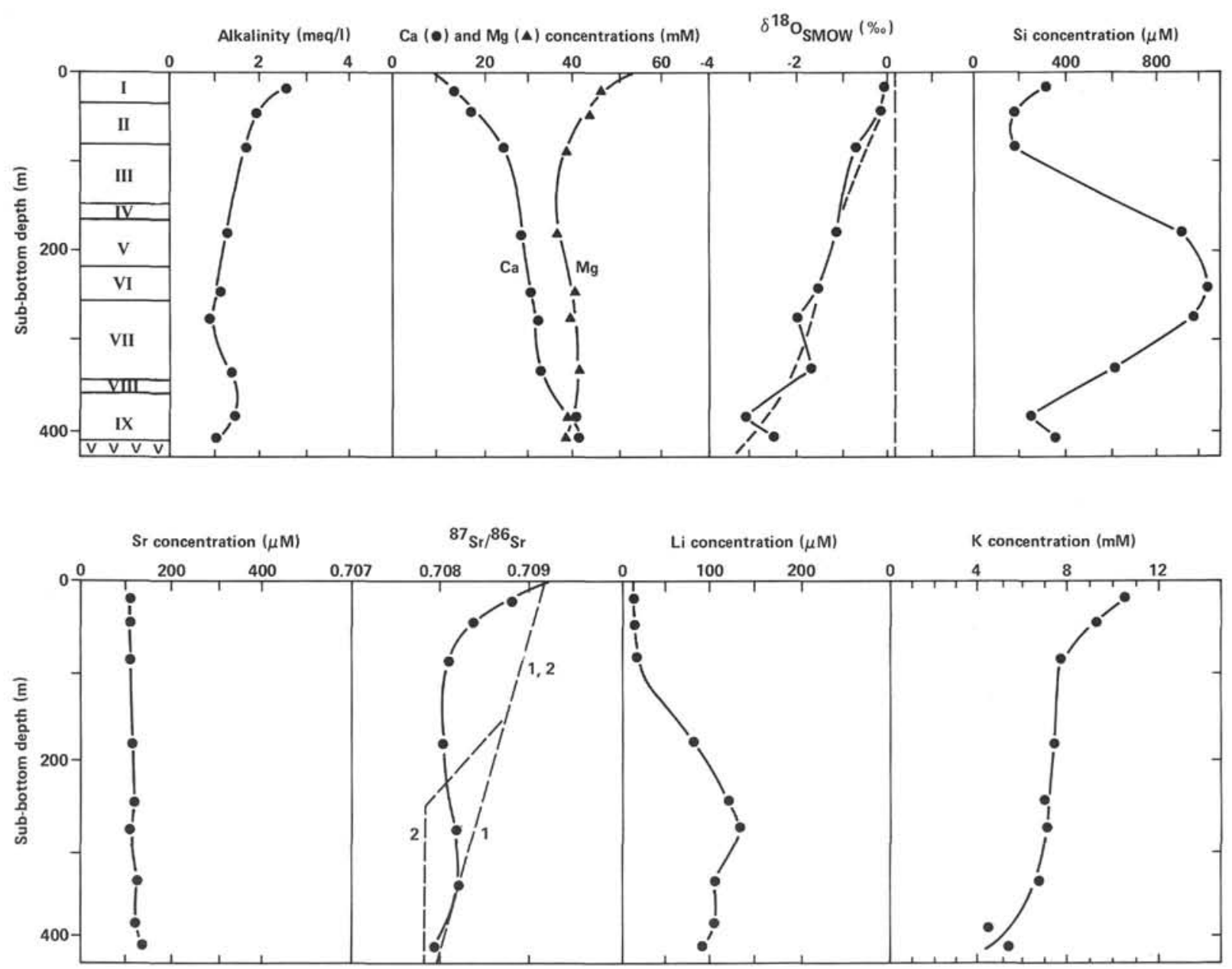

Figure 5. Interstitial water profiles, Site 543 (combining data from Table 1 for Holes 543 and 543A). Age units: $\mathrm{I}=\mathrm{Quaternary}, \mathrm{II}=$ Pliocene, III = lower Miocene, IV = middle Miocene, V = lower Miocene, VI = Oligocene, VII = Eocene, VIII = Paleocene, IX = Upper Cretaceous; see Figure 2. Dashed lines = contemporaneous seawater (1: Hart and Staudigel, 1978; 2: Burke et al., 1982).

per sediment column, and if a substantial contribution to the calcium signal originates in the lower-lying sediments or basalts, the observed correlation between calcium and magnesium contents could be expected. The $\mathrm{Ca}-\delta^{18} \mathrm{O}$ correlation (Fig. 6) does indicate curvature, with values of $\delta^{18} \mathrm{O}$ near the bottom of Hole 543A being $\sim-3 \%$. This nonlinear correlation between Ca concentration and $\delta^{18} \mathrm{O}$ suggests production of calcium in the sediments, with a relatively small associated signal in $\delta^{18} \mathrm{O}$. We shall return to this problem in the following section.

Data for dissolved strontium suggest little carbonate influence. Dissolved-silica content reflects biogenic sili$\mathrm{ca}$, and lithium appears to be released in the siliceous zone. Uptake of potassium is indicated in the upper sediments, as well as in the basal sediments or underlying basalts.

\section{ALTERATION OF VOLCANIC MATERIAL}

The distribution of ${ }^{87} \mathrm{Sr} /{ }^{86} \mathrm{Sr}$ at all three sites clearly demonstrates that at Sites 541 and 542 all ratios are below contemporary seawater values, as they are in the upper $200 \mathrm{~m}$ of sediments at Site 543 . At Site 543 no signif- icant increases in dissolved-strontium content with depth are observed, so we can estimate the volcanic contribution to the ${ }^{87} \mathrm{Sr} /{ }^{86} \mathrm{Sr}$ ratio. For this we will take ${ }^{87} \mathrm{Sr} /{ }^{86} \mathrm{Sr}$ to be 0.708 at $100 \mathrm{~m}$ sub-bottom (for contemporaneous seawater, ${ }^{87} \mathrm{Sr} /{ }^{86} \mathrm{Sr} \approx 0.709$ ). If volcanic material were to have an ${ }^{87} \mathrm{Sr} /{ }^{86} \mathrm{Sr}$ ratio of 0.703 before alteration, then the contribution by volcanic material to the ${ }^{87} \mathrm{Sr} /$ ${ }^{86} \mathrm{Sr}$ ratio of dissolved strontium would be $\sim 17 \%$. This should be a minimum estimate because it ignores diffusion and assumes a relatively low ratio in volcanic matter (Elderfield and Gieskes, 1982). Thus, exchange with volcanic material in the sediments must be substantial, though of course in the absence of data for strontium in the solid phase we cannot estimate the amount of volcanic matter involved.

In Hole 541 at $\sim 150 \mathrm{~m}$ sub-bottom, the ratio ${ }^{87} \mathrm{Sr} /$ ${ }^{86} \mathrm{Sr}$ is $\sim 0.7083$. At this depth the concentration of dissolved strontium is $\sim 300 \mu \mathrm{M}$, and contemporaneous seawater has an ${ }^{87} \mathrm{Sr} /{ }^{86} \mathrm{Sr}$ ratio of $\sim 0.709$. Allowing for input from contemporaneous carbonate, (i.e., with regard to the increase of dissolved strontium), one calculates that volcanic material has contributed at least $30 \%$ of the observed ${ }^{87} \mathrm{Sr} /{ }^{86} \mathrm{Sr}$. Of particular interest, of course, 

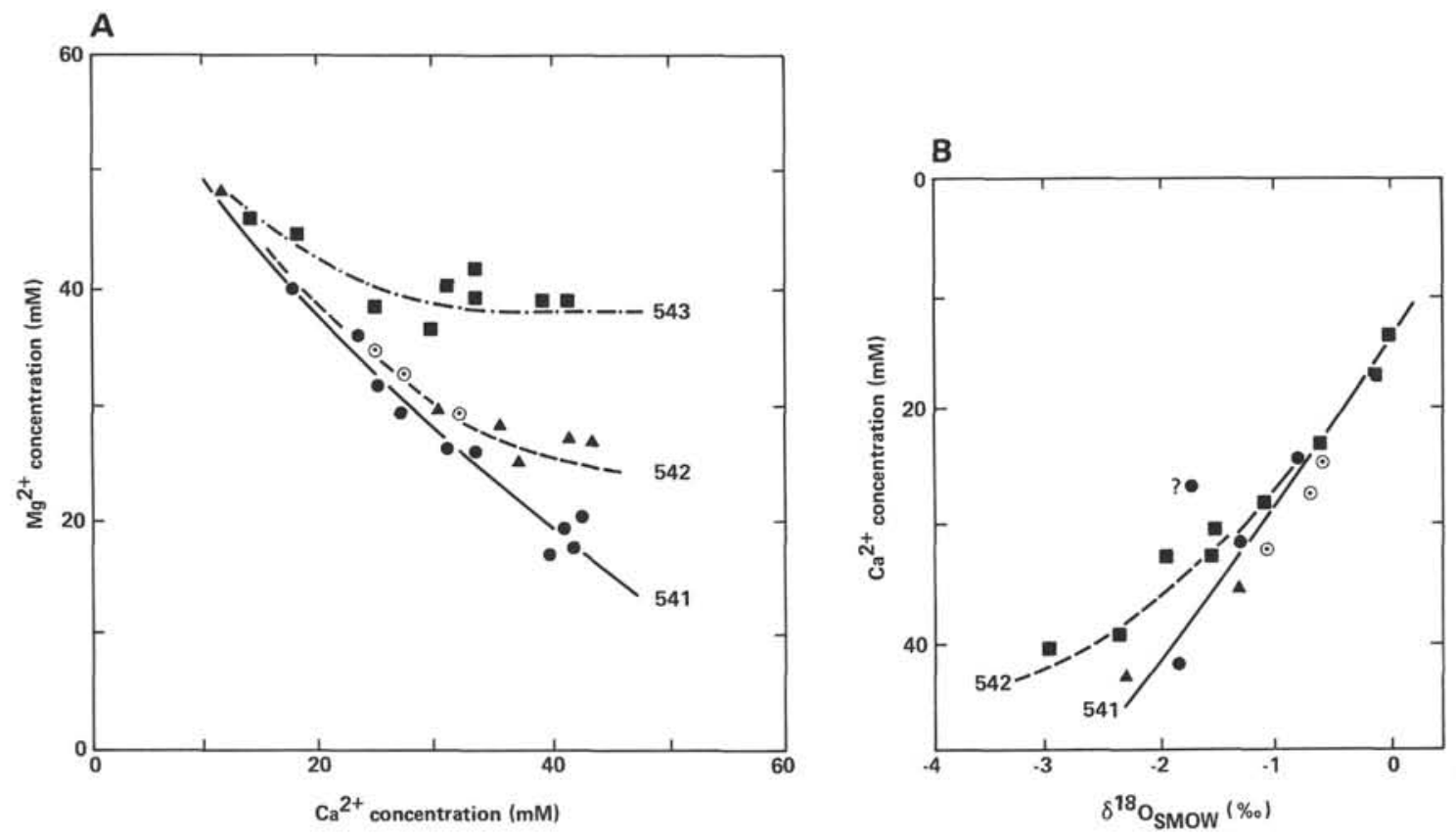

Figure 6. Correlations between $\mathrm{Ca}$ and $\mathrm{Mg}(\mathrm{A})$ and $\delta^{18} \mathrm{O}(\mathrm{B})$ for Sites $541(\bullet), 542(\Delta)$, and $543(\square) . \odot=$ in situ values.

is that changes in the concentration of dissolved magnesium over depth are also larger at Site $541(\Delta \mathrm{Mg}$ $\sim 25 \mathrm{mM})$, compared with those at Site $543(\Delta \mathrm{Mg} \sim$ $17 \mathrm{mM})$. These changes are approximately proportional to the volcanic contributions to the ${ }^{87} \mathrm{Sr} / 86 \mathrm{Sr}$ signal, and would therefore support the contention that magnesium uptake is associated with alteration of volcanic matter. Of course, we realize that comparisons of this nature are not based on extensive information.

The lower ${ }^{87} \mathrm{Sr} /{ }^{86} \mathrm{Sr}$ ratios in lower Miocene sediments at Sites 541 and 542 can be understood in terms of lesser contributions from contemporaneous carbonates (lower dissolved-strontium concentrations).

Previously we observed that at Site 541 a substantial portion of the $\delta^{18} \mathrm{O}$ must have been generated in the sediments, presumably as a result of alteration of volcanic matter. With a mean value of $\delta^{18} \mathrm{O}$ of $-1 \%$, one estimates that in a closed system about $5-15 \mathrm{~m}$ of ash must be responsible for the decrease in $\delta^{18} \mathrm{O}$ (Lawrence and Gieskes, 1981). This estimate could be increased when the possibility of diffusive exchange with the overlying ocean is also considered. However, this estimate would require alteration of $\sim 20 \%$ of the sediments in the upper $150-200 \mathrm{~m}$ of the sediment column. From the data on the ${ }^{87} \mathrm{Sr} /{ }^{86} \mathrm{Sr}$ ratio, we estimated that volcanic contributions to the changes in magnesium and calcium at Site 543 were substantially less than at Site 541 . For this reason the expected $\delta^{18} \mathrm{O}$ signal would also be much less, so that the reactions in the upper $100 \mathrm{~m}$ at Site 543 would cause only a minor perturbation in the $\delta^{18} \mathrm{O}$-vs.-depth profile, which at this site seems to be governed mainly by reactions occurring in the underlying basalts. The nonlinearity in the $\mathrm{Ca}-\delta^{18} \mathrm{O}$ correlation for Site 543 (Fig. 6) is caused mainly by abundant production of calcium in the upper sediment column, accompanied by a relatively small depletion in $\delta^{18} \mathrm{O}$ and a significant decrease in
${ }^{87} \mathrm{Sr} /{ }^{86} \mathrm{Sr}$. Though basalt alteration causes a substantial depletion in $\delta^{18} \mathrm{O}$ (Lawrence and Gieskes, 1981), the decrease in ${ }^{87} \mathrm{Sr} / 86 \mathrm{Sr}$ associated with this process appears very small (Elderfield and Gieskes, 1982). This makes ${ }^{87} \mathrm{Sr} /{ }^{86} \mathrm{Sr}$ a very sensitive indicator of contributions by volcanic matter dispersed in the sediments to changes in calcium and magnesium concentrations at many DSDP sites (Gieskes and Lawrence, 1981).

\section{CONTEMPORANEOUS ${ }^{87} \mathrm{Sr} /{ }^{86} \mathrm{Sr}$ CURVE}

Recent studies of the ${ }^{87} \mathrm{Sr} /{ }^{86} \mathrm{Sr}$ ratio in carbonate rocks as a function of age (Burke et al., 1982) have revealed a curve that largely deviates from previous estimates, particularly for Tertiary and Cretaceous rocks (Peterman et al., 1970; Dasch and Biscaye, 1971; Veizer and Compston, 1974). In a recent paper, Elderfield and Gieskes (1982) reviewed the available body of data on the ${ }^{87} \mathrm{Sr} /$ ${ }^{86} \mathrm{Sr}$ ratio of dissolved strontium in interstitial waters and showed that at many sites alteration of volcanic matter leads to ${ }^{87} \mathrm{Sr} /{ }^{86} \mathrm{Sr}$ ratios considerably lower than contemporaneous seawater values. In their study, use was made of the polynomial developed by Hart and Staudigel (1978) for the contemporaneous ${ }^{87} \mathrm{Sr} /{ }^{86} \mathrm{Sr}$ curve. With the proposed new curve of Burke et al. (1982), many sites still show deviations below contemporaneous ${ }^{87} \mathrm{Sr} /{ }^{86} \mathrm{Sr}$ values. Thus, even at sites with carbonates, the influence of alteration of volcanic matter may not be negligible, as was suggested by Elderfield and Gieskes (1982) and Elderfield et al. (1982).

Hole 543 is relatively free of carbonate, and in Figure 5 we present the contemporaneous seawater curves of Hart and Staudigel (1978) and of Burke et al. (1982). Of interest is the close agreement of our data, below $300 \mathrm{~m}$ sub-bottom, with the curve of Hart and Staudigel. Of course, little carbonate is present at this site, with the possible exception of the basal sediments. Devi- 
ations of our data from the curve of Burke et al. (1982) may well result from diffusion and from reactions in the upper sediment column having gained recent significance; this could cause a non-steady-state profile in ${ }^{87} \mathrm{Sr} /{ }^{86} \mathrm{Sr}$, leading to the minimum at $\sim 100 \mathrm{~m}$ sub-bottom (cf. magnesium minimum at same depth). At present we are undertaking a study of carbonate sediments with the specific purpose of investigating further how the alteration of volcanic matter may affect the distribution of ${ }^{87} \mathrm{Sr} /{ }^{86} \mathrm{Sr}$ in both the interstitial waters and carbonates.

\section{ADVECTION IN THE SEDIMENTS?}

Drilling at Site 542 was terminated because of inadvertent "packing" of Hole 542A, with clear evidence of overpressure at the base of the hole, possibly associated with migration of interstitial fluids (see the Site Report for Site 542, this volume. In addition, temperature measurements during the logging program (Davis and Hussong, this volume) indicated that relatively warm waters did flow up the hole after penetrating or contacting the downgoing sediment slab. This again raises the question of possible fluid migration through the sediments before drilling was initiated. The further question remains, however: in what direction would such migration take placeupward or lateral?

In situ temperature data (Davis and Hussong, this volume) for Site 541 did indicate a possible linear temperature gradient with depth, though the instrumental data are of very low quality. Linear temperature gradients would rule out any significant upward advective flow (Crowe, 1981), though some such flow might occur. We therefore decided to examine our concentration-vs.-depth profiles for indications of upward migration of fluids. Because diffusion coefficients of salts are much lower than diffusion coefficients of heat curvature in inte-stitial water, gradients might offer evidence of upward advective flow, albeit at low rates (Crowe, 1981).

Neither the distribution curves of dissolved strontium nor the ${ }^{87} \mathrm{Sr} /{ }^{86} \mathrm{Sr}$ profiles suggest significant upward advection at Sites 541 and 542 . This is especially clear from a comparison with the profiles for Site 543, the Oceanic Reference Site. At this site no advection should occur, and we have already shown that concentration gradients for calcium and magnesium can best be understood in terms of alteration of volcanic matter in the sediment column. As noted before, the calcium-magnesium correlation is nonlinear; that is, reactions must be at least partly responsible for observed concentration changes in these components. Profiles for dissolved lithium suggest no significant upward advection either at Site 541 or at Site 542 .

We conclude that if advection of interstitial fluids is associated with the subducting sediment slab, this advection is not occurring in an upward direction.

\section{ACKNOWLEDGMENTS}

This research was supported by grants NSF-OCE-80-23966 (JMG), NERC GR3/4444 (HE), and NSF-OCE-80-24044 (JRL).
We thank the shipboard chemist Dr. David Ripley for his diligent work, Dr. J. Natland for discussion, and Drs. R. McDuff and F. L. Sayles for their reviews of the manuscript.

\section{REFERENCES}

Burke, W. H., Denison, R. E., Hetherington, E. A., Koepnick, R. B., Nelson, H. F. and Otto, J. B., 1982. Variation of seawater ${ }^{87} \mathrm{Sr} /$ ${ }^{86} \mathrm{Sr}$ throughout Phanerozoic time. Geology, 10:516-519.

Crowe, J., 1981. Mechanisms of heat transport through the floor of the Equatorial Pacific Ocean [Ph.D. thesis]. Woods Hole/MIT, p. 231.

Dasch, E. J., and Biscaye, P. E., 1971. Isotopic composition of strontium in Cretaceous-to-Recent pelagic foraminifera. Earth Planet. Sci. Lett., 11:201-204.

Elderfield and Gieskes, J. M., 1982. Sr isotopes in interstitial waters of marine sediments from Deep Sea Drilling Project cores. Nature, 300:493-497.

Elderfield, H., and Gieskes, J. M., Baker, P. A., Oldfield, R. K., Hawkesworth, C. J., and Miller, R., $1982 .{ }^{87} \mathrm{Sr} /{ }^{86} \mathrm{Sr}$ and ${ }^{18} \mathrm{O} /{ }^{16} \mathrm{O}$ ratios, interstitial water chemistry and diagenesis in deep-sea carbonate sediments of the Ontong Java Plateau. Geochim. Cosmochim. Acta, 46;2259-2268.

Emerson, S., Grundmanis, V., and Graham, D., 1982. Carbonate chemistry in marine pore waters: MANOP Sites C and S. Earth Planet. Sci. Lett., 61:220-232.

Epstein, S., and Mayeda, T. K., 1953. Variation of ${ }^{18} \mathrm{O}$ content of waters from natural sources. Geochim. Cosmochim. Acta, 4:213-224.

Gieskes, J. M., 1974. Interstitial water studies, Leg 25. In Initial Reports of the Deep Sea Drilling Project (eds. Simpson, E. S. W., Schlich, R., et al., Init. Repts. DSDP, 25: Washington (U.S. Govt. Printing Office), 361-394.

1983. The chemistry of interstitial waters of deep sea sediments: interpretation of Deep Sea drilling data. In Riley, J. P., and Chester, R. (Eds.), Chemical Oceanography 8:221-269.

Gieskes, J. M., and Johnson, J., 1981. Interstitial water studies, Leg 59. In Kroenke, L. Scott, R., et al., Init. Repts. DSDP, 59: Washington (U.S. Govt. Printing Office), 627-630.

Gieskes, J. M., and Lawrence, J. R., 1976. Interstitial water studies, Leg 35. In Hollister, C. D., Craddock, C., et al., Init. Repts. DSDP, 35: Washington (U.S. Govt. Printing Office), 407-424.

1981. Alteration of volcanic matter in deep sea sediments: evidence from the chemical composition of interstitial waters from deep sea drilling cores. Geochim. Cosmochim. Acta, 45:1687-1703.

Hart, S., and Staudigel, H., 1978. Oceanic crust: age of hydrothermal alteration. Geophys, Res, Lett., 5:1009-1012.

Hawkesworth, C. H., and Elderfield, H., 1978. The strontium isotope composition of interstitial waters from Sites 245 and 336 DSDP. Earth Planet. Sci. Lett., 40:423-432.

Jahnke, R. Heggie, D., Emerson, S., and Grundmanis, V., 1982. Pore waters of the central Pacific Ocean: nutrient results. Earth Planet. Sci. lett., 62:233-256.

Lawrence, J. R., Drever, J. I., Anderson, T. F., and Brueckner, H. K., 1979. Importance of volcanic matter alteration in the sediments of Site 323: chemistry, $\mathrm{O}^{18} / \mathrm{O}^{16}, \mathrm{Sr}^{87} / \mathrm{Sr}^{86}$. Geochim. et Cosmochim. Acta, 43:573-588.

Lawrence, J. R., and Gieskes, J. M., 1981. Constraints on water transport and alteration in the oceanic crust from the isotopic composition of pore water. J. Geophys. Res., 86:7924-7934.

McDuff, R. E., 1981. Major cation gradients in DSDP interstitial waters: the role of diffusive exchange between seawater and upper oceanic crust. Geochim. Cosmochim. Acta, 45:1705-1713.

Peterman, Z. E., Hedge, C. E., and Tourtelot, H. E., 1970. Isotopic composition of strontium in seawater thorugh Phanerozoic time. Geochim. Cosmochim. Acta, 34:105-120.

Veizer, J., and Compston, W., $1974 .{ }^{87} \mathrm{Sr} /{ }^{86} \mathrm{Sr}$ composition of seawater during the Phanerozoic. Geochim. Cosmochim. Acta, 38: 1461-1484.

Date of Initial Receipt: February 18, 1983

Date of Acceptance: August 10, 1983 